Persp. Teol. 35 (2003) 55-70

\title{
A FÉ CRISTÃ NO OCIDENTE: ENTRE A CALIDEZ EMOCIONAL E A PARRESIA EVANGÉLICA
}

Gabino Uríbarri SJ

Partindo-se de instâncias muito diversas, a capacidade evangelizadora da Igreja nos países ocidentais é preocupante. Em particular, João Paulo II sublinhou repetidas vezes a necessidade de um novo impulso e da revisão dos modelos de evangelização ${ }^{1}$. Dentro desse horizonte mais global, proponho uma meditação sobre um aspecto parcial, ainda que importante e arraigado, do modo de viver a fé nos países ocidentais, o qual tem a ver com nossa capacidade ou ineptidão para transmitir a boa notícia da fé no Senhor Jesus. Seguirei o esquema típico das meditações de Santo Inácio nos Exercícios Espirituais. Começo com uma composição de lugar, contemplando o aspecto singular da fé no Ocidente que me interessa: a centralidade do bem-estar emocional nesta forma de inculturar a fé. Em seguida, proponho uma contemplação de textos e situações, especialmente do Novo Testamento, para deixarnos empapar e transformar osmoticamente e por contágio. Para terminar, recolho alguns aspectos da contemplção para iluminar a situação inicial.

\footnotetext{
${ }^{1}$ Sem pretensão de exaustividade, cf. JOÃO PAULO II: Redemptoris Missio, 33; Pastores dabo vobis, 18; Tertio millennio adveniente, 42, 45; Novo millennio ineunte, $15,40$.
} 


\section{A fé cristã como "boa notícia" no Ocidente}

\subsection{O Evangelho é uma "boa notícia"}

Hoje em dia, nós, cristãos, entendemos claramente que o evangelho é uma boa notícia e percebemos nossa fé como uma boa notícia. Arraigou-se na nossa consciência que a palava eu-aggélion significa, precisamente, boa notícia. Assim consideramos, na mesma linha do Novo Testamento, que o nascimento, a vida, a pregação, a morte e a ressurreição do Senhor Jesus são uma boa notícia de salvação para toda a humanidade. O evangelista Marcos, por exemplo, começa seu escrito com as palavras: "Começo do evangelho de Jesus Cristo, Filho de Deus"(Mc 1,1), dando-nos a entender que tudo o que virá depois será uma explicitação dessa frase tão densa. Com nossa fé, situamo-nos diante de uma boa notícia para todos, mas especialmente para os pobres (Lc 4,16-21; 7,22). A vida de Cristo Jesus supõe a chegada da graça e da verdade (Jo 1,17), do perdão e da reconciliação com Deus (2Cor 5,18-21). E assim poderíamos continuar citando uma quantidade enorme de textos muito conhecidos: as refeições de Jesus com os pecadores, suas curas e milagres, a parábola do filho pródigo, a interpretação paulina das conseqüências salvíficas da morte de Cristo na cruz com o perdão dos pecados, a justificação etc.

Receber tal boa notícia, logicamente, deve ser traduzido de alguma maneira que traga benefícios e seja boa para a própria vida. As boas notícias afetam-nos, alegrando-nos, dando-nos ânimo, sonhos, esperança. Por outra parte, que seja "bom", e portanto, "boa notícia", entende-se sempre no seio de uma cultura, a qual proporciona significados para entender o que é bom e humanizante para a pessoa humana.

\subsection{Nossa inculturação do evangelho como "boa notícia"}

Em nossa cultura ocidental, própria dos países industrializados, circula uma série de significados, socialmente bastante partilhados por todos, sobre o que seja uma vida humana que deu certo. Certamente um dos seus componentes indispensáveis é uma capacidade aquisitiva mínima, tendendo inclusive a ser elevada, como traço pertencente ao que se denomina "qualidade de vida". Não obstante, seria um disparate, hoje, para nós, cristãos, entender que o evangelho é uma boa notícia porque proporciona uma alta capacidade aquisitiva ou porque nos coloca em uma posição ótima para atingi-la (como se se tratasse de posições excelentes). Além disso, a realidade cotidiana desmente-o tão taxativamente que não é necessário deter-nos muito nisso. Contudo, outro dos componentes do ideal de uma pessoa adulta, madura e feliz, humanamente desenvolvida, o qual também se firmou na nossa cultu- 
ra, é o bem-estar emocional. E é aqui, pois, que estamos situando com relativa facilidade nosso modo de entender que a fé cristã é um "evangelho", uma boa notícia. Vejamos alguns aspectos que o indicam.

\section{a) Deus como aliado do bem-estar psico-afetivo}

Um dos elementos da inculturação da fé nos países ocidentais industrializados passa pela consideração de que a fé é uma boa notícia para nossa vida psico-afetiva. Em primeiro lugar, porque nos fala do amor e da acolhida por parte de Deus. E isso é uma grande ajuda para a aceitação de si mesmo e para o próprio amadurecimento. Assimilamos profundamente a conexão entre confiança básica, da qual falara o psicólogo E. Erikson ${ }^{2}$, como fundamental para a vida e para a fé cristã. Aqui se mostraria como a fé cristã contribui com uma resposta eficaz e consistente às necessidades humanas, potenciando seu pleno desenvolvimento. A confiança básica seria obtida, segundo Erikson, se tudo vai bem, na primeira etapa da evolução psico-afetiva, graças ao carinho incondicinal e à dedicação da mãe. E este seria o primeiro degrau indispensável para uma personalidade madura, livre, saudável e, sobretudo, feliz. Ora, a fé cristã assegura-nos mais profundamente ainda a possibilidade de arraigar-nos nessa confiança básica, como uma fundamentação ao mesmo tempo metafísica e afetiva. Deus, como amor, é o criador e a raiz última da existência. Mas Deus também é um amor pessoal, que se debruça sobre cada um de nós, singularmente sobre minha pessoa. Assim, Deus é uma boa notícia para minha confiança básica, para meu bem-estar psico-afetivo, minha maturidade, minha liberdade e minha felicidade.

\section{b) A comunidade cristã como lar cálido}

A fé não somente nos põe em contato com esse Deus amoroso, que fundamenta, sustenta e gera, através de suas mediações, nossa confiança básica, mas também nos abre para um âmbito de relações acolhedoras na comunidade cristã. Um dos elementos mais característicos da comunidade cristã nos parece que são as relações fraternas; tradução franca e simples de um dos principais modelos de Igreja sancionado pelo Concílio Vaticano II: a "Igreja comunhão".

Nas sociedades capitalistas, industriais e consumistas, vivemos o mundo como um âmbito de relações de trabalho tremendamente competitivas e exigentes, de uma maneira tal que ameaçam despedaçar as pessoas, considerando-as friamente como mercadorias ou números nos balanços contábeis. Nessas sociedades, passamos horas imersos em ambientes massificados e anônimos (transportes públicos, grandes centros

\footnotetext{
${ }^{2}$ Esse autor menciona pela primeira vez esse aspecto, recorrente em seu pensamento, em E. ERIKSON, Infancia y sociedad, Ediciones Hormé: Buenos Aires, $1970,3^{a}$ ed., p. 62 ss.
} 
comerciais) e de relações frias. Diante desse mundo hostil, grupos cristãos de estrutura mais leve nos proporcionam a boa notícia da pertença a um grupo marcado pela cordialidade, pelo encontro interpessoal, onde é possível a relação pessoal e personalizante. Chegando ao seu extremo, para os grupos cristãos juvenis das grandes cidades, a religião consiste, antes de mais nada, na pertença ao grupo ${ }^{3}$, o qual se converte em seio materno e nutriz onde se sente acolhido. Daí a tendência, não somente das comunidades de jovens, que encontramos em alguns grupos e comunidades cristãs, que passam a ser e a funcionar como verdadeiros "nichos emocionais", onde se vive um cristianismo cálido, debruçado sobre as relações psico-afetivas cálidas no interior do grupo, de tom fortemente intimista. Nesta forma de viver a fé cristã como boa notícia, a comunidade passa a ser, antes de mais nada, um lugar de encontro, de consolo, de ânimo, de relação, de pertença, de sustentação, onde sou significativo etc.

Encontrar um grupo assim resulta em uma grande ajuda para a vida ordinária e, por isso, vive-se como boa notícia. Certamente, a comunidade cristã deve encontrar vias ordinárias para expressar de modo inteligível que é uma fraternidade. Contudo, a pergunta que eu me faço diante desses grupos cristãos é se esse modo de viver o evangelho como boa notícia deixou de lado o fato de ser uma boa notícia pública e para todos. Ou seja, se nesses grupos o evangelho deixou de ser algo público ${ }^{4}$, que se vive pública e abertamente e se proclama também publicamente. Dá a impressão de que esse cristianismo emocionalmente cálido corre um sério perigo de seqüestrar a dimensão pública da fé, para convertê-la em algo de tipo mais privado e intimista. Nesse caso, a fé pertenceria, sobretudo, ao âmbito do grupo pequeno e à esfera privada, mas apenas com repercussão ou presença nos âmbitos públicos e no conjunto da sociedade.

Creio que há três carências que revelam essa forma de viver a fé, explicitando-a e exercendo-a nesses marcos de tipo mais fechado e sem incidência pública. Em primeiro lugar, esse tipo de comunidade cristã tende a segregar uma liturgia que não está aberta, que não é pública. É necessário como que uma "carteirinha" de pertença ao grupo para poder participar em suas celebrações litúrgicas, ao passo que a liturgia é por si mesma uma celebração e uma manifestação pública e aberta da fé. A liturgia desses grupos serve para a sua coesão interna, mas geralmente não tem capacidade de penetração evangelizadora na sociedade.

${ }^{3}$ A. TORNOS / R. APARICIO, ¿Quién es creyente en España hoy?, PPC: Madrid, 1995, p. 29,42,106-7.

${ }^{4}$ L. NEWBIGIN, Una verdad que hay que decir. El evangelio como verdad pública, Santander: Sal Terrae, 1994. 
Em segundo lugar, nos cansamos de voltar ao tema da carência de presença do elemento cristão no âmbito político. No caso espanhol, temos deixado essa esfera de lado, com se não tivesse diretamente a ver com a fé. Certamente o terreno político é tremendamente complexo e está cheio de armadilhas que assustam de antemão qualquer pessoa honrada e impoluta (corrupção, efeitos nocivos do poder, intrigas dentro dos partidos etc.). Mas não deixa de ser um sintoma significativo do tipo de enraizamento que a fé está tendo em nossos ambientes o fato de que não se gerem vocações cristãs políticas, que queiram aí servir ao bem comum e se porem, a partir dessa plataforma, a serviço dos mais necessitados. Contrastam enormemente os números de pessoas ativas e comprometidas nas comunidades eclesiais com as cifras de políticos explicitamente cristãos ativos. Dá a impressão de que desviamos, no melhor dos casos, a ação de transformação social para o âmbito da caridade ou das ONGs. Que diferença em comparação com os países que forjaram a atual Europa comunitária, depois da Segunda Guerra mundial! Esse políticos atuaram a partir de sua conviç̧ão cristã e ainda somos herdeiros de sua ousadia e de seus sonhos.

Em terceiro lugar, outro tanto acontece com a criação artística. Em todo o âmbito do cinema, da pintura, da narrativa, da poesia, da escultura etc., o elemento cristão está socialmente sub-representado em relação ao número de pessoas que crêem. E me refiro simplesmente aos assim chamados "praticantes", não somente aos cristãos de nome.

Deixo de lado um quarto campo, também susceptível de menção: os meios de comunicação social, que supõem outro âmbito público. Também aqui ser-nos-ia difícil sair muito airosos, e por isso nossos bispos andam preocupados e potenciam com maior ou menor acerto os meios de comunicação explicitamente confessionais. A extensão bastante generalizada entre as comunidades cristãs dos aspectos que mencionei, ao menos do segundo e terceiro pontos, manifesta que nos encontramos diante de uma forma bastante estendida de viver a fé.

\section{c) A prática religiosa como investimento em bem-estar emocional}

Esse tipo de identidade cristã, profundamente marcado pela calidez das relações dentro da comunidade cristã, dá cor ao sentido das práticas religiosas. Pensemos, por exemplo, na pertença eclesial, concretizada na pertença a esses grupos cristãos de estrutura mais leve. Um dos elementos imprescindíveis e básicos que configuram tal pertença eclesial radica em "sentir-se bem", em gostar de estar no grupo. Isso sucede nos grupos de catecumenato de adultos, ou de leitura da Bíblia, ou de casais, ou de jovens universitários. Essa razão termina por ser determinante. Alguém poderia pertencer a uma confraria, por exemplo, por tradição familiar, ou por uma promessa, ou porque forma parte da trama da vida social de tal cidade ou região. E há alguns anos 
se pertencia àqueles grupos cristãos por outras razões, que hoje nos fazem sorrir: para garantir para si um enterro digno ou uma boa sepultura, ou para receber as graças de pertencer a tal grupo, ou pela formação religiosa e o estímulo que se recebiam; sem, entretanto, ignorar a importância das relações sociais que se geravam nesses grupos (basta pensar em algumas ilustres Congregações Marianas dirigidas por jesuítas). Contudo, nas regiões onde hoje a religiosidade popular não está mais arraigada, aqueles grupos somente sobrevivem se conseguem gerar um alto grau de bem-estar emocional. Trata-se de uma condição inelutável, ainda que, evidentemente, isso pode vir acompanhado de outros ingredientes.

Essa maneira de viver a fé cristã é capaz de integrar outros elementos da fé a partir do ponto de vista da boa notícia que eles supõem para o bemestar emocional e seu sustento. Apresentarei dois exemplos. $\mathrm{O}$ primeiro deles é a oração. Fazer oração, com freqüência, é focalizado, nesses ambientes, na busca da consolação, do bem-estar emocional diante de Deus e comigo mesmo. A oração deveria ser um lugar de paz, de encontro consigo mesmo. Por isso torna-se tão difícil, hoje, perserverar nos momentos em que a oração começa a tornar-se incômoda, ou simplesmente se entra em um período de sequidão. Então a oração deixa de cumprir sua missão (secreta), que não era tanto a de ajudar a crescer em amizade com Deus, dedicar-se ao seu louvor e avançar em despojamento, quanto sentir-se o melhor possível como se é, sem grandes custos.

Algo similar acontece, em segundo lugar, com o compromisso social desse estilo de comunidade. "Fazer voluntariado" é uma experiência que leva a sentir-se bem, porque se está fazendo algo em favor dos demais, está havendo um comprometimento, e se está exercendo e praticando a fé. A pergunta chave é quanto o tempo de voluntariado, o contato com os pobres e com a pobreza, toca verdadeira e profundamente a nossa vida. Se chega a penetrar-nos, em nossa afetividade e sensibilidade, no nosso modo de julgar ou se se trata antes de um verniz "politicamente correto" para que nos sintamos suficientemente bem conosco mesmos. Criamos relações significativas com essas pessoas ou as atendemos momentaneamente para voltar ao consolo de nosso nicho afetivo?

\subsection{Propósito}

Quer o vivamos de um ou outro modo, continua sendo certo que o evangelho é uma boa notícia: para nós cristãos, para os pobres e para toda a humanidade, para todos. Portanto, uma boa notícia pública. Mais que uma reprimenda e uma intimação voluntariosa à mudança, creio que pode ajudar-nos prestar atenção a um conceito - a parresia - e a um modo de vida - a vivência "parresíaca" da fé - bastante presente no Novo Testamento, para deles aprender. Contemplemos as 
ações, as atitudes, o modo de viver, acolher e de pregar o evangelho das primitivas comunidades cristãs para que aprendamos delas, por contágio e por inveja de tal modo de vida, tão pleno, tão humanizante, tão alegre e, em algumas questões, tão diferente do nosso.

\section{A "parresia"}

Antes de entrar em maiores detalhes, ajudará ter uma idéia primeira, ainda que seja aproximada, do significado do termo parresia, o qual estaremos continuamente manejando de agora em diante ${ }^{5}$. Em espanhol, "parresia" não pode ser traduzido por um vocábulo único que expresse todos seus matizes. É significativo que não tenha sido traduzido nem em aramaico nem em siríaco ${ }^{6}$. O substantivo parresia significa: abertura, franqueza, sinceridade, abertura de espírito e de expressão, confiança gozosa, valentia. O verbo correspondente, parresiázomai, quer dizer: falar com franqueza ou liberdade, ter confiança, ter ânimo.

\subsection{Significado profano de "parresia"}

\section{a) Etimologia}

A palavra grega parresia procede de pan (tudo) - rêsis ${ }^{7}$ (palavra). Daí que o significado mais primário seja "dizer tudo" ou, mais propriamente, "a liberdade para dizer tudo".

\section{b) Significado político}

O primeiro emprego atestado do nosso termo procede do âmbito da vida política. Designa, de um modo específico, a capacidade de que gozam os cidadãos de pleno direito de ter liberdade de palavra na ekklesía, que era a assembléia da pólis grega. Nem os escravos nem os estrangeiros possuíam esse direito. Contudo, o cidadão livre possuía o direito de expressar sua opinião livremente, sem censura e com toda franqueza e abertura. Como se vê, a dimensão pública faz parte essencial do conceito. Esse aspecto se manterá ao longo de todas as suas modulações.

\footnotetext{
${ }^{5}$ Tomo todos os dados e resumo de: E. PETERSON, 'Zur Bedeutungsgeschichte von ' $\pi \alpha p p \eta \sigma i \alpha$ '", em Zur Theorie des Christentums, I (FS R. Seeberg), W. KOEPP (Hrg.),

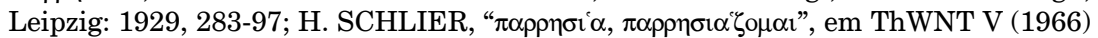
869-884; H. CHR. HAHN, “Confianza, valentía”, em L. COENEN / E. BEYREUTHER / H. BIETENHARD, Diccionario teológico del Nuevo Testamento I, Salamanca:

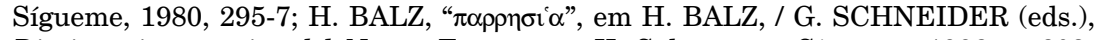
Diccionario exegético del Nuevo Testamento II, Salamanca: Sígueme, 1998, c. 802811. Aí se poderão encontrar mais dados e bibliografia.

${ }^{6} \mathrm{H}$. BALZ, op. cit., 805.

${ }^{7}$ Por trás de rêsis está o verbo erô = dizer, que provém da raiz indo-européia wer. Essa raiz está por trás de termos como Wort, word, verbum, verbo.
} 
Para nós, esse significado mostra-se próximo à faculdade de que gozam o deputados no parlamento, protegidos pelas leis para poder manifestar, com toda abertura e franqueza, suas opiniões políticas, de qualquer tipo que sejam. O direito especial de serem pessoas com uma função parlamentar as protege.

Desse significado básico principal procede também a perversão do conceito, que passa a designar sem-vergonhice, charlatanice ou desfaçatez quando se abusa da parresia ou não se usa dela corretamente. Assim, pois, a falação fanfarrona e mal-educada não tem a ver com a autêntica parresia.

Nessa época, a parresia aparece estreitamente aparentada com:

- O poder (exousía) de falar. Quem tem parresia possui a faculdade e a capacidade de falar. A parresia é um poder, uma capacitação.

- A verdade (alétheia) para dizer o que as coisas são. Pois a parresia atende precisamente à faculdade de relatar de viva voz o que corresponde à realidade, ao fatos.

- E a valentia para expor publicamente o que as coisas são.

\section{c) Significado nas relações interpessoais}

A partir do âmbito político, adquiriu, de modo derivado, um significado próprio na esfera das relações interpessoais, na esfera privada. Nesse terreno, a parresia significa a confiança, a franqueza e a abertura própria dos amigos, que não se ocultam as coisas nem se enganam uns aos outros. Situa-se no âmbito das relações entre iguais e da amizade: no campo da philía.

Entendo que esse significado também nos é próximo, pois com relativa freqüência nos vemos em situações desse tipo. Na relação interpessoal entre amigos reconhecemos que podemos falar francamente, ou que não ganhamos nada com ocultar algo ou que não queremos fazer o desfavor de ocultar parte da verdade, mesmo que inicialmente doa a nosso amigo ou lhe possa ser incômoda. A franqueza é um pressuposto e um componente da verdadeira amizade.

\section{d) Significado moral}

Foram, sobretudo, os filósofos cínicos os quais, a partir do sentido político primordial, outorgaram à parresia um conteúdo moral. Nesse sentido, o autêntico filósofo moral é aquele que vive livremente, sem estar condicionado pelo que dirão ou guiado por interesses espúrios. Isto significa seguir uma conduta reta segundo sua consciência. Por isso, comporta-se de modo aberto e livre (= com parresia) diante de seus concidadãos, quem quer que sejam. Por isso "quem tem parresia, 
leve uma vida pública" ${ }^{\prime \prime}$, no sentido de aberta, sem ocultar-se e sem dissimular. $\mathrm{O}$ verdadeiro filósofo moral não leva nem uma vida dupla, e menos ainda, uma existência clandestina.

\subsection{A parresia no Antigo Testamento e no Judaísmo Helenista}

\section{a) A parresia no Antigo Testamento}

Na tradução grega do Antigo Testamento (chamada dos LXX, porque a tradição a atribuiu a setenta sábios), o substantivo parresia aparece 12 vezes, ao passo que encontramos o verbo em 6 ocasiões. Entre seus matizes, destacam-se estes três:

1. A parresia expressa a situação do livre, em contraposição ao escravo. Um exemplo claro é Lv 26,13 (LXX)": "Eu sou o Senhor vosso Deus, que vos tirei do Egito onde éreis escravos e vos regatei do cativeiro e de vosso jugo e vos conduzi com a cabeça bem alta (metà parresías)".

2. Também refere-se à prerrogativa de estar livre e alegremente diante de Deus, sem que nada impeça o contato com Ele. A parresia expressa a liberdade, a confiança e a gozosa segurança do justo diante de Deus. Assim o entende Jó 22,26 (LXX): "Cheio de parresia (parresiasthése) diante do Senhor, contente levantarás a vista em direção ao céu" (cf. também Jó 27,10 [LXX]).

3. Por último, a parresia contém um tom escatológico, especialmente em Sb 5,1: [no dia do juízo] "Estará então o justo em pé com grande confiança (parresía pollê), em presença dos que o afligiram, e desprezaram seus trabalhos". Esse sentido escatológico está unido à justiça do justo (Pr 13,5; 20,9), isso é, a uma forma de vida; e à parresia de Deus. Assim, o justo tem um acesso livre e franco a Deus, sem temor algum; e Deus, por sua parte, escuta a oração do justo e se mostra como um juiz justo, cheio de parresia (S1 93,1). Tal parresia manifestase especialmente na oração e está acompanhada de alegria.

\section{b) A parresia na literatura judeu-helenista}

Para nosso objetivo, não é necessário aprofundar o significado do termo parresia nos ambientes judeus, impregnados de cultura grega da época próxima ao Novo Testamento. Simplesmente podemos ressaltar que, em linhas gerais, continua-se com o uso que aparece no Antigo

\footnotetext{
${ }^{8}$ H. SCHLIER, op. cit., 872

9 Traduzo, do texto grego, este texto de Jó e o seguinte. Quem consultar uma tradução moderna se surpreenderá ao encontrar uma versão algo diferente, pois o texto grego da LXX e o texto grego massorético nem sempre coincidem.
} 
Testamento. Assim, a parresia é própria do justo, do que cumpre a Lei. Manifesta-se, sobretudo, na oração, como um modo específico, franco e confiante, de tratar com Deus. Por último, também adquire um tom escatológico: pode-se ter acesso à presença do trono de Deus ou do messias e de todo o seu esplendor, com alegria e com confiança no prêmio. Essa alegria confiante expressa-se através do louvor.

\subsection{A parresia no Novo Testamento}

O substantivo parresia aparece 31 vezes no Novo Testamento e o verbo em 9 ocasiões. Trata-se, portanto, de um conceito bastante importante no Novo Testamento, com uma freqüência não desprezível.

Antes de entrar em mais detalhes, chama a atenção que a expressão parresia designe ao mesmo tempo: o modo de Jesus realizar sua missão, o modo dos apóstolos e cristãos anunciá-la e vivê-la e a confiança escatológica para o dia do juízo. Dá-se, pois, um fundamento cristológico para uma forma de vida cristã que expressa a verdadeira acolhida das realidades que a vida e a morte de Cristo Jesus geraram. Descendo mais ao concreto, convém destacar que o termo pertence ao âmbito da proclamação da mensagem evangélica e da relação com Deus. Passarei em revista rapidamente seus matizes mais destacados nos escritos em que aparece.

\section{a) A parresia no corpus joanino}

1. Para o evangelho de João, a parresia é uma característica do modo de Jesus revelar-se. A revelação de Jesus é pública, não no escondimento (en kryptô) ou de modo clandestino (Jo 18,20; 7,4-5.25). Jesus manifestou-se de modo aberto diante do mundo (kósmos): "Tenho falado abertamente (parresía) diante de todo o mundo; tenho ensinado sempre na sinagoga e no Templo, onde se reúnem todos os judeus e não tenho falado nada ocultamente" (Jo 18,20). Convém notar que se mencionam instâncias públicas e de tipo oficial - o Templo, a sinagoga - como os lugares públicos de reunião dos judeus. A pregação de Jesus, dirigida ao povo de Israel, levou completamente a sério as instâncias públicas e oficiais judaicas, até o ponto de terminar por custar-lhe a vida.

É característico que esse modo de Jesus falar abertamente e em público não seja entendido a não ser pelos que têm fé (Jo 7,4s; 11,14). Algo disso se reflete no único texto que possuímos nos sinóticos em que se menciona a parresia, no quadro do anúncio da paixão: "Falava disso abertamente (parresía)" (Mc 8,32). Os discípulos, contudo, não captam o que Jesus lhes quer dizer.

Contudo, uma vez que irrompa a "hora" da glorificação de Jesus e se produza o dom do Espírito, os discípulos captarão tudo: "Aproxima- 
se a hora na qual já não vos falarei em parábolas, mas antes com toda clareza (parresía) vos falarei a respeito do Pai" (Jo 16,25; cf. 16,29). Percebe-se que é na hora escatológica da revelação de Jesus que os discípulos podem compreender profundamente o significado da mensagem de Jesus. Como se vê, existe uma certa tensão entre o falar abertamente e em parábolas ou mediante sinais que exigem uma certa inteligência. Contudo, a parresia de Jesus opõe-se a um falar escondido (en kryptô), que permanecesse desconhecido e que fizesse impossível o acesso à revelação ou que esta fosse pública e compreensível. Por outra parte, e continuando com as tensões, o modo de Jesus revelarse acontece mediante sinais públicos e cognoscíveis, mas não consiste em chamar ostensivamente a atenção sobre si, mas sim em atuar à vista de todos, como o testemunha Jo 18,20.

2. Em 1 Jo, a parresia supõe a boa consciência, que nos permite estar confiante e abertamente diante de Deus $(3,2115,14)$. Isso se dá graças ao Espírito Santo $(3,21)$ e se expressa, sobretudo, na oração confiante, que Deus escuta $(3,22 ; 5,14 \mathrm{~s})$.

Também se dá uma parresia escatológica $(2,28 ; 4,17)$, que expressa uma abertura diante de Deus e do juiz vindouro, sem nenhum tipo de vergonha ou de medo. "Pois a parresia é o reflexo da consumação do amor de Deus por nós. O permanecer no amor, que não conhece o temor, já que guarda os mandamentos, se manifestará no juízo futuro, no qual nós temos livre acesso e relação aberta com Deus, isso é parresia"10.

\section{b) A parresia nos Atos dos Apóstolos}

O significado básico nos Atos dos Apóstolos é o da "abertura da mensagem missionária no sentido da intrepidez, da franqueza e da confiança gozosa perante os críticos e os adversários"11, e se percebe especialmente nas figuras de Pedro e Paulo. Trata-se, pois, predominantemente de uma parresia diante dos homens. De uma valentia, intrepidez e confiança para falar em público, especialmente diante de ambientes hostis: "Vendo a valentia (parresía) de Pedro e João, sabendo que eram homens sem instrução nem cultura, estavam maravilhados" $(4,13)$; "E agora, Senhor, leva em consideração suas ameaças e concede a teus servos que possam pregar tua palavra com toda valentia (metà parresías páses)" $(4,29)$. Como se vê, trata-se de um dom do Senhor Jesus $(14,3)$ e do Espírito $(4,31)$.

Paulo também proclama abertamente a mensagem $(9,27 ; 28,31)$. Não se trata de ostentação ou de busca de notoriedade, mas sim da autoridade e da intrepidez que o Exaltado concede a seus mensageiros.

${ }^{10}$ H. SCHLIER, op. cit., 880.

${ }^{11}$ H. BALZ, op. cit., 807. 
Encontramo-nos, pois, com um dom público para a construção da comunidade e o cumprimento de sua missão, isso é, de um carisma cabal.

\section{c) A parresia nos escrito paulinos}

Nos escritos paulinos, a parresia reflete uma característica da existência cristã e, particularmente, da apostólica (Flp 1,20; Ef 3,12). Aqui o conceito é um pouco mais complexo. Para Paulo, trata-se tanto de uma parresia diante dos homens (2 Cor 3,12; Ef 6,20; 1 Ts 2,2; 2 Cor 7,4; 1 Tm 3,13; Fm 8), no anúncio do evangelho; quanto de uma parresia diante de Deus (2 Cor 3,12; Flp 1,20; Ef 3,12), que implica uma relação franca, aberta, confiante.

Comecemos com um texto: "Conforme ao que aguardo e espero, que de modo algum serei confundido; antes, que com plena segurança (en páse parresía), agora como sempre, Cristo será glorificado em meu corpo, por minha vida ou por minha morte"(Flp 1,20). Paulo espera com toda segurança que Cristo seja glorificado nele, de modo aberto e público, quer seja com a sua vida, quer seja com a sua morte, com seus êxitos ou com seus fracassos. Trata-se, no fundo, de algo parecido com o que se pode suspeitar como a atitude vital e crente do atual pontífice em suas viagens apostólicas, apesar de sua enfermidade. Quer seja porque antes viajara pleno de faculdades, anunciando o evangelho, ou que agora o faça no limite de sua forças físicas, parece que João Paulo II estima que assim seja glorificado publicamente o Senhor, a quem serve na saúde e na enfermidade.

2Cor 3,12-17 representa um desenvolvimento muito interessante. Paulo menciona a parresia no início: "Tendo, pois, esta esperança, falamos com toda valentia (pollê parresía)" $(3,12)$. Moisés cobria-se com um véu diante dos israelitas, depois de ter estado conversando com Deus (Ex 34,33.35). Nós cristãos não precisamos cobrir-nos diante do homens. Pelo contrário, graças ao dom do evangelho e ao Espírito, desperta-se em nós, na esperança, o resplendor da glória. Pois, por Cristo e pela fé nele, temos acesso seguro a Deus (Ef 3,12). Para Paulo, aqui se expressa a diferença entre o resplendor da glória do Antigo Testamento, que se eclipsava, e o atual, que não se eclipsa. $O$ contato com o resplendor da glória, que não se eclipsa, produz um tipo de relação com as pessoas, no qual não se dissimula a impregnação do resplendor da glória que acontece em nós quando entramos em contato com ela. Pelo contrário, o fruto final de tudo é a liberdade: "Porque o Senhor é o Espírito, e onde está o Espírito do Senhor, aí está a liberdade" (2 Cor 3,17).

Esse modo de atuar diante dos homens pressupõe a fé e a boa conduta: "Porque os que exercem bem o diaconado alcançam um posto 
honroso e grande inteireza (pollèn parresían) na fé em Cristo Jesus" (1Tm 3,12 ). De novo, encontramos a conexão entre a parresia e o modo de vida ajustado à consciência e à verdade, igual ao que acontecia com o justo que cumpria a lei, segundo o Antigo Testamento e o judaísmo helenista, ou com o ideal do filósofo moral coerente dos cínicos.

Como já vimos, para o corpus joanino, a parresia é um dom: "Conseguimos a valentia de ânimo (eparresasámetha), por meio de nosso Deus, para anunciar-vos o evangelho"(1Tes 2,2). O evangelho outorga sua própria parresia ao seu próprio mensageiro (Ef 6,19-20).

A parresia é aparentada ao poder (exousía), por exemplo, em Fm 8: "Pelo que, ainda que tenha em Cristo bastante liberdade (pollèn parresían) para mandar o que convém".

De especial interesse é $\mathrm{Cl}$ 2,15: "E uma vez despojados dos Principados e as Potestades, os exibiu publicamente (en parresía), incorporando-os ao seu cortejo triunfal". O autor está considerando que o acontecido na cruz implica uma notoriedade cósmica da salvação escatológica, pois se manifesta seu poder e seu triunfo diante de todos os Principados e das Potestades, dos poderes de magnitude cósmica. Por essa mesma razão, manifesta-se publicamente a preeminência da cruz e sua salvação acima de toda outra instância que pretenda um senhorio escatológico. A metáfora que o autor emprega é muito plástica. Pelo menos os imperadores romanos, mesmo sem serem originais, organizavam grandes festas quando regressavam vitoriosos de uma campanha, na qual ou tinham conseguido afastar os perigos ou tinham aumentado a glória de Roma. Um dos momentos principais consistia, precisamente, no desfile triunfal, no qual as tropas eram aclamadas pelo povo, e se mostrava parte do butim. Nessa ocasião, fazia-se passar os prisioneiros algemados, especialmente os mais significativos, para o escárnio público e a algazarra. $\mathrm{O}$ autor de Colossenses está interpretando que, com a cruz de Cristo, acontece um desfile cósmico-escatológico, no qual todos os poderes adversários da cruz de Cristo aparecem em ferros e ligados ao carro vencedor de Cristo. Em definitivo, a parresia cristã fundamenta-se no triunfo escatológico de Cristo como sua última raiz. O triunfo escatológico do Senhor Jesus nos liberta e instiga para a confiança gloriosa.

\section{d) A parresia na Carta aos Hebreus}

Neste último sentido, a Carta aos Hebreus insiste com clareza suficiente. A parresia reflete um modo característico dos cristãos serem. Pois agora, graças a Cristo e a seu sangue, temos acesso livre e seguro a Deus: "Aproximemo-nos, portanto, confiadamente (metà parresías) do trono de graça, a fim de alcançar misericórdia e encontrar graça para uma ajuda oportuna" $(4,16)$. A imagem que está por trás e que nos 
pode iluminar é a das cortes dos imperadores na Antiguidade: os faraós ou os imperadores persas. Uma pessoa comum não tinha de modo algum acesso à presença do rei ou do imperador, à sala do trono. Chegar ali era totalmente impossível e um cidadão comum teria que contentar-se com tratar com intermediários de terceiro ou quarto escalão. O trono ocupa um lugar inacessível e excelso. Quem ali entrasse teria que comportar-se com toda reverência, temor e humildade, consciente de uma graça absolutamente imerecida e desproporcional.

Contudo, nós, graças ao sangue de Jesus $(10,19)$ e a seu sacrifício $(4,14 \mathrm{~s})$, temos acesso livre ao santuário, à presença do próprio Deus, maior e mais excelso que qualquer imperador terreno. E podemos entrar de maneira confiante na presença de Deus e do juiz, cheios de esperança $(3,6)$. Isso implica, certamente, a fé e a coerência com suas exigências $(10,22)$, pois pressupõe e expressa a pertença à casa de Deus $(3,14.16)$.

\section{Refletindo sobre nós mesmos}

Para terminar, podemos resumir alguns aspectos mais destacados da parresia segundo o Novo Testamento, sondando algum tipo de aplicação à nossa circunstância atual.

\subsection{Dimensão pública da fé cristã}

Acabamos de comprovar que a fé cristã contém de modo essencial uma dimensão pública, a qual lhe é inerente. A pregação e a atuação de Jesus é pública, aberta. Ainda que não se possa qualificar de fanfarronada nem de jactância ou exibicionismo, não há dúvida de que a sua mensagem e sua vida não transcorreram no escondimento (en kryptô), refugiado na privacidade de um grupo pequeno, nem tampouco na clandestinidade. Isso não nega a importância da fé para entendê-lo nem que também fizesse uso das parábolas. Assim, pois, Jesus não praticou uma espécie de ostentação triunfalista e arrogante, que tanto nos incomoda. Não obstante, perceber com clareza que a dimensão pública é inerente à revelação e ao ministério de Jesus não pode não interpelar nosso cristianismo emocionalmente cálido.

Nossa transmissão da revelação deve inspirar-se obrigatoriamente no modo como Jesus se revelou. Assim se percebe nos apóstolos e nos primeiros discípulos: pregavam e se apresentavam diante dos demais homens cheios de parresia, de valentia, aberta e publicamente. Assim atuam diante dos judeus e dos gregos, de um modo notório e público, também diante de dificuldades e dos inimigos. Não praticam uma pregação do evangelho envergonhada, triste, reservada, nem no escondimento. Também não foi assim o ministério público do Senhor Jesus. 


\subsection{Um modo de anunciar a fé e de vivê-la interconectados}

O cristão, em geral, como seguidor do Senhor Jesus e, ainda com mais força, os que ostentam algum tipo de cargo público na Igreja (sacerdotes e religiosos) são chamados, por coerência, a levar uma vida pública no sentido, ao menos, que era o dos filósofos cínicos. Quer dizer, não se entende que o cristão tenha que se envergonhar e dissimular a sua condição, inclusive diante dos adversários da fé. Portanto, se nos situássemos em um cristianismo clandestino e intimista, estaríamos afastandonos dessa conexão entre fé e forma de vida, característica da parresia.

A conduta de Paulo representa um exemplo claro do que quero dizer. Seu modo de atuar permite-lhe viver em parresia no sofrimento, na tribulação e no êxito. Trata-se de uma confiança básica que é expressão da esperança cristã. Paulo está persuadido de que o Senhor triunfa em nós e conosco, graças à nossa vida de entrega a Ele. Essa segurança situa-se nas antípodas do desalento, e produz alegria, confiança, intrepidez, arrojo e convicção de que o Senhor faz e fará sua obra em nós. Porque por esse meio Ele é glorificado e dá a conhecer sua própria glória. Assim, a propagação da fé e a vida a serviço da mensagem é marcada pela confiança, valentia, ousadia, a partir da segurança não de um êxito em nossa empresas, mas sim de que a graça de Deus triunfará em nós, seja na tribulação, seja na consolação.

Esse estilo de anúncio e vivência da fé implica um modo particular de relação com Deus. Essa relação está marcada pela franqueza, pela sinceridade e pela confiança. E por isso, manifesta-se, sobretudo, na oração confiante, aberta, franca, confiante e familiar. Essa proximidade permite reconhecer a verdade da orientação da própria vida e se é ou não conforme à vontade de Deus. Seguindo uma vida desse estilo, espera-se com paz e consolo que Deus escute e atenda a oração (cf. Lc 1,13; Jo 9,31), como escutou a seu Filho Jesus Cristo (cf. Jo 11,41-42).

Essa familiaridade diante de Deus contém, também, uma dimensão escatológica. Abre-se na direção da confiança escatológica para estar diante de Deus no dia do juízo, para apresentar-se sem vergonha diante do trono da majestade de Deus e do Juiz, mas sim com confiança, abertura, segurança e alegria. Não há dúvida de que essa confiança gera uma grande paz e uma grande força. Firmados aqui, na liberdade e na alegria dessa graça enorme, podemos enfrentar com intrepidez a difícil tarefa da evangelização.

\subsection{Tudo é graça}

A parresia nos recorda que esse modo de vida e de relação aberta e confiante com Deus é graça, dom do Espírito de Deus e do Senhor 
Jesus. É um dom que se confere aos cristãos. Portanto, se nos víssemos na falta dele, poderíamos implorar por ele. A parresia recorda-nos algumas linhas de como nossa vida transcorre no Senhor ou em Deus ou em nome do Senhor Jesus, e que são eles os que atuam em nós. É a força do Espírito quem se faz presente em nós e nos transforma em mensageiros da boa notícia. Como um dom escatológico, somente se percebe na fé e no Espírito.

Esse arrojo, intrepidez e confiança procedem do novo acesso que Cristo nos abre às realidades celestiais. Agora podemos entrar no santuário que seu sangue nos abriu, ao passo que, antes, o acesso tão íntimo e familiar com Deus nos estava vedado. Cristo mesmo cravou na cruz o documento que nos condenava $(\mathrm{Cl} 2,14)$. De tal maneira que sua hora (segundo João) e seu dom do Paráclito é o que nos leva a viver de outro modo: como autênticos cidadãos livres da ekklesía, da Igreja, que podem testemunhar aberta, valente e confiantemente toda a vida e o júbilo que brotam do lado aberto de Cristo Jesus.

Tradução do original espanhol por Claudio Paul, SJ.

Gabino Uríbarri Bilbao, SJ é licenciado em filosofia (Universidad Pontificia Comillas, Madrid); licenciado em teologia (Philosophisch-Theologische Hochschule "Sankt Georgen" - Frankfurt a. M.); doutor em teologia (Universidad Pontificia Comillas). Professor de teologia dogmática na Faculdade de Teologia da Universidad Pontificia Comillas, desde 1994. Atualmente ensina escatologia e história da teologia e é diretor do Departamento de Teologia Dogmática e Fundamental. Tem-se interessado pela teologia pré-nicena. Publicou vários artigos sobre esse tema: Monarquía y Trinidad, UPCo, Madrid, 1996; La emergencia de la Trinidad inmanente en Hipólito y Tertuliano, UPCo, Madrid, 1999. Também trabalhou a teologia da vida religiosa e a iluminação teológica da pastoral vocacional, com vários escritos sobre essa temática, entre eles: "Reavivar el don de Dios" (2 Tim 1,6). Una propuesta de promoción vocacional, Sal Terrae, Santander, 1997; Portar las marcas de Jesús. Teología y espiritualidad de la vida consagrada, Desclée, Bilbao, 2002, $2^{a}$ ed. Também ocupou-se com a evangelização e as relações Igreja-sociedade.

Endereço: Departamento de Teología Dogmática y Fundamental Facultad de Teología

Universidad Pontificia Comillas

c/ Universidad Comillas, 3

28049 Madrid - Espanha

e-mail: guribarri@teo.upco.es 